\title{
Problems of German Periodicals
}

$\mathrm{H}^{\mathrm{OR}}$ AT LEAST the past half century science - and technology in America and elsewhere have leaned heavily on and been profoundly influenced by the work of German scientists. The chief medium of communication, naturally, has been German publications, and particularly periodical literature. For an interim in the First World War, research workers in the United States were deprived of these publications, and the loss was keenly felt. Following the war the Germans gradually re-established their prestige in the scientific world, and their journals again became considered indispensable by chemists, physicists, biologists, and other scientists everywhere. The question of cost, with which the present article is primarily concerned, does not appear to have become a serious issue until about 1924 , after the period of wild inflation in Germany, and the stabilization of the mark, though there were occasional complaints concerning the instability of prices in the inflation years.

So far as the present writer's investigations have been able to determine, the first formal action protesting the prices of German books and periodicals was taken by the Medical Library Association at a meeting on June IO, I924. A committee, composed of Charles Frankenberger, J. Christian Bay, and Joseph Wilson, brought in a resolution expressing disapproval of German publishers' "unreasonable and unjustifiable charges for their publications to foreign subscribers and especially discriminating against American subscribers." It was recommended that purchases be discontinued until a more equi- table policy was adopted. The resolution was approved unanimously. ${ }^{1}$

A prompt reaction was received from the German publishers' association, Deutscher Verlegerverein. In a letter to the Medical Library Association, dated Oct. I I, I924, a representative of the German publishers denied there were any differences between prices to German and to foreign subscribers and maintained that German books and periodicals were no more expensive, and in some instances were cheaper, than similar publications in England and America.

Undaunted, the American committee stuck to its guns, repeating its charge of exorbitant prices, at least on the part of certain German publishers, and pointing out that the new plan adopted by Virchow's Archiv and other journals, i.e., of having no established number of issues or fixed subscription rate, caused increases in some instances of several hundred per cent in the annual cost to libraries. ${ }^{2}$

In 1928 English librarians, led by Wilfrid Bonser of Birmingham University, entered the fray. In response to a communication from Baini Prashad, of the Zoological Survey of India, objecting to the excessive prices of German scientific journals, Dr. Bonser published a list of physiological and chemical journals, comparing annual costs of British, American, German, and other European periodicals. It was shown that the German titles were from three to four times as high as similar English pub-

\footnotetext{
${ }^{1}$ Medical Library Association Bulletin 14:4, July 1924 .

${ }^{92}$ Medical Library Association Bulletin 14:39-42, October 1924-January 1925; 15:23-27, October 1925.
} 
lications and, in the field of physiology, cost more than all the other countries combined. As remedies, Dr. Bonser proposed more rigorous editing to reduce quantity and thereby costs or, as a last resort, cancellation of subscriptions. He reported that at the International Physiological Congress in Stockholm in 1926 a suggestion had been made for the German physiologists to do their own printing to reduce prices. At the same meeting German editors promised to try to cut down the length of published articles. $^{3}$

\section{Pearl Study}

A mildly dissenting voice was raised by a scientist, Raymond Pearl, in 1926, on the basis of his study of the cost of biological books from various countries. Dr. Pearl concluded that the per page cost of German books in the field of biology was less than either the English or American, though substantially higher than the French. His investigation, however, was limited to books and did not consider serial publications. Furthermore, in subsequent reports for 1927 and 1928 , Dr. Pearl discovered a "consistent and steady increase in the average price per page" of commercially published German biological books. ${ }^{4}$

The Medical Library Association and Bonser reports were the opening skirmishes in what soon developed into a major engagement, in which library associations, scientific societies, bookdealers, publishers' organizations, and even governments participated. Before reviewing the actions of these groups, however, it would be well to look at the background, and see what was

3 Bonser, Wilfrid. "Prices of Periodical Scientific Publications." Nature 121:538-39, Apr. 7. 1028; and idem, "The Cost of German Biological Periodicals." Library Association Record 6:252-56, December 1928. -Pearl, Raymond. "The Cost of Biological Books in 1926." Quarterly Review of Biology $1: 606-08$, October 1926; idem, "The Cost of Biological Books in 1928." responsible for the controversial situation.

Several factors accounted for the disproportionately high charges made by the Germans. Foremost, perhaps, was the practice of swelling the size of the journals by the inclusion of doctoral dissertations, published in full, and of other monographs or Festschriften appearing as supplementary volumes, all of which added to the expense of production. Second, was the custom of paying a per page rate to authors of scientific articles, thus encouraging a writer to pad his contribution by such devices as long historical preambles and philosophical discussions, already familiar to his readers, before arriving at the meat of the matter. The salaries of editors were also fixed by the amount of material published. These methods were approved by the publishers, who were thereby enabled to set higher prices for their publications. Another usage, a cause of many complaints, was the failure, previously referred to on the part of the publishers, to establish fixed subscription rates for many periodicals. Each part or each volume was priced separately when issued. A subscriber could, therefore, never estimate exactly, or even approximately, how much a particular title would cost in any given year. Several volumes of Festschriften, Ergänzungsbäde, Sonderhafte, Beihefte, or Abhandlungen might be added unexpectedly, doubling the amount a library had allowed in its budget for the title. Furthermore, some supplementary parts had scarcely any relation to the journals they supplemented. As one complainant stated, "the number of volumes printed annually is gauged by the capacity of subscribers to absorb the output without too much indignation or open protest." ${ }^{5}$ Finally, abnormally large trade discounts,

5 Robert, Alfred L. "The Comparative Cost of Medical Journals." Medical Library Association Bulletin 20:1 $40-55$, April 1932. 
amounting to 25 per cent, added to costs.

All the German publishing policies cited were contrary to those followed in the United States and England. Each had the effect of increasing prices. Direct protests to German publishers' associations and to individual publishers were met either with defenses of the existing order of things or with promises of reforms which usually failed to materialize.

In the flush years of the late twenties, with money plentiful, relatively speaking, libraries were able to carry the heavy financial burden imposed by the German journals. After the arrival of the great economic depression in 1929, however, the situation soon became intolerable.

\section{Discussion at 1931 Conference}

Following up the 1928 Bonser study, Charles H. Brown and Alfred L. Robert supplied the critics with additional factual ammunition. At the r93I A.L.A. conference Mr. Brown discussed the "Cost of Subscriptions to Current Foreign Periodicals," comparing the annual subscription costs of fourteen German periodicals for 1924-25 and 1930 and revealing the "alarming" increases which had taken place during this period. He introduced a resolution, adopted by the Administrators Round Table, deploring the high prices, because excessive costs would reduce the purchase and use of German scientific publications in this country, and recommending that the A.L.A. Book Buying Committee intercede with appropriate organizations in Germany. ${ }^{6}$ Later in the year Mr. Brown published a report on the problem as it affected his own library, Iowa State College. Current periodical subscriptions, nearly exclusively in science and technology, he reported, rose from $\$ 8,000$ per year in 1925 to $\$ 18$,000 in

- A.L.A. Bulletin 25:519, September 1931.
I93I, an increase attributable almost entirely to the cost of German periodicals. For a group of fifty German, French, English, and American periodicals, selected as most valuable for scientific research, the average annual subscription price of the German titles in 1930 was more than six times as high as the English, seven times the American, and eight times the French. On a per page basis, the discrepancies were not quite so striking, though still wide; the German journals averaged $\$ 3.78$ per printed page, as contrasted with $\$ 1.37$. for the English, $\$ .82$ for the American, and $\$ 1.17$ for the French. As possible solutions, the author suggested some cancellations of subscriptions, interlibrary cooperation, reduction of the length of articles, elimination of poorly written and less important articles, and compensation to the publishers for decreases in cost by increasing the number of subscribers. ${ }^{7}$

Alfred L. Robert, librarian of Columbia University's College of Physicians and Surgeons, also contributed an extensive analysis of American, British, French, German, and other medical journals, comparing number of volumes, total pages, annual cost, per volume cost, and cost per page for 1930-3I. His findings substantiated Mr. Brown's in every respect. Columbia's expenditures for German medical periodicals were $\$ 3234$ for the year, as against $\$ 577$ for American journals, with German subscriptions costing five times more than the American, eight times more than the British, and sixteen times more than the French. ${ }^{8}$

A similar report with reference to costs, from the John Crerar Library, stated that for 1930 its German medical periodicals

\footnotetext{
"Brown, Charles H. "A Hazard to Research." Journal of Higher Education 2:420-26, November 1931; also appeared in Library Journal $57: 26 \mathrm{r}-65$, Mar. 15,

${ }^{1932}$. "Comparative Cost of Medical Journals." Medical Library Association Bulletin 20:140-55, April 1932.
} 
came to $\$ 3000$, while all its American journals in the field were only $\$ 1000 .^{9}$

\section{Situation of German Librarians}

The plight of German librarians and scientists in this situation was as serious as in other countries. One commentator remarked that prices were so far out of reach of most German subscribers that the publications seemed to be issued to increase the foreign prestige of German science rather than for home consumption. Perhaps stimulated by protests from abroad, librarians and scientific societies in Germany began exerting pressure on publishers for changes. In the forefront of this movement was Georg Leyh, librarian of the University of Tübingen. Dr. Leyh urged his colleagues to side with American and British librarians campaigning for price reductions, for all had the same interests. As a remedy for the swollen bulk of scientific periodicals, Dr. Leyh proposed elimination of doctoral dissertations, throwing the legal obligation for publication upon the authors and for distribution on the university libraries. ${ }^{10}$

A letter from the Medical Library Association, in January 1933, to German scientific societies and editors asked their cooperation in bringing about a reduction in the cost of current German periodicals. ${ }^{11}$ Numerous responses, with almost unanimous support for the association's objectives, were received. A similar communication from the English Linnean Society to the German botanical, zoological, and anatomical societies was sent earlier, in April 1932. In June of the same year the Comité

\footnotetext{
9 John Crerar Library. Thirty-Sixth Annual Report for the Year 1930. Chicago, r931, p. 26.

${ }^{10}$ Leyh, Georg. "Die Deutschen Zeitschriftenpreisen und die Amerikanischen Bibliotheken." Zentralblatt für Bibliothekswesen 50:377-88, May I933; summarized and discussed in: Brown, Charles $H$. "German Periodicals in American Libraries: Deflation or Extinction?" Library Journal 58:525-28, June 15,1933 .

${ }^{11}$ Medical Library Association 'Bulletin 21:90-9r, January r933.
}

International des Bibliothèques at Bern passed a resolution recognizing the justification for repeated protests against high prices for German scientific journals, and called attention to the great loss which would be suffered by everyone concerned if libraries were no longer able to purchase these periodicals. The Verein Deutscher Wissenschaftlicher Verleger was requested to use any means in its power to bring down prices, by cutting the size of publications and by lowering profits. ${ }^{12}$ During this period numerous other protests were published in scientific and library periodicals, and complaints registered by scientific and medical associations, both in this country and abroad.

Under the constant barrage, the German publishers were getting uneasy but were not yet ready to retreat or capitulate. Their defenses were varied, e.g., prices would not seem high if budgets had not been cut, a reduction in the size of periodicals would retard the progress of research, and it was impossible to foresee at the beginning of a year how much material should be printed in a journal. None of these arguments was convincing to the critics.

\section{Subcommittee on German Periodicals}

With the whole situation apparently heading for a showdown, Charles $\mathrm{H}$. Brown became chairman in the fall of 1932 of the A.L.A. Subcommittee on German Periodicals. Under his able and dynamic guidance, building on the efforts of preceding groups and persons, substantial progress was made within a relatively short time toward a settlement of the major issue. As previously noted, the new chairman had been concerned with the problem for some time prior to his appointment on the committee.

In December $1932 \mathrm{Mr}$. Brown called together in Chicago a group of represen-

12 Actes du Comité International des Bibliotheques. 5me. Session. Bern, 1932, p. 46. 
tatives of library associations to consider a proposal from Ferdinand Springer, head of the firm of Julius Springer, foremost German publisher of scientific literature. Dr. Springer suggested the establishment in America of a central buying agency to which he would be willing to grant a 25 per cent discount. He also offered to allow a special discount to members of certain American scientific societies. The scheme met with slight favor. Objections included doubts as to its feasibility; its failure to solve the major difficulty, i.e., high prices of certain periodicals; and the hardships it would create for libraries' regular dealers. The concessions offered obviously fell far short of expectations and were not acceptable. ${ }^{13}$

By mid-1933 American librarians were ready for more drastic measures. The Medical Library Association's Committee on the Cost of Current Medical Periodicals, under the chairmanship of Mrs. Eileen R. Cunningham, who had been an active participant in the campaign for several years, invited $\mathrm{Mr}$. Brown to meet with it in June 1933 at Chicago. There a series of resolutions was passed, to the effect that: no library should subscribe to any periodical without a fixed annual subscription price stated in advance; the cooperation of other library groups in the United States and abroad should be enlisted to help establish more equitable prices for medical and other scientific journals; and, failing any substantial reduction on excessively expensive journals for 1934, libraries should cancel subscriptions, except in certain established zones in America and Canada. For the purposes of the last recommendation, the United States was divided into nine regions, with the aim of cutting down to one subscription for each periodical for each region if it should become necessary. Looking toward

\footnotetext{
12 Medical Library Association Bulletin 22:9-10, August 1933 .
}

the future, Mr. Brown suggested that these zones might eventually be used as a basis for wider library cooperation, e.g., in plans for subject specialization among libraries. ${ }^{14}$

\section{Efforts toward Compromise}

At this juncture German publishers apparently decided some compromises were necessary. Four organizations, representing authors, publishers, and librarians, met at Münster on August 3, and there the Börsenverein der Deutschen Buchhändler announced it would expect all its members in future to state subscription prices in advance for all periodicals, and, further, it would expect a reduction of at least 20 per cent in the content and price of inflated periodicals. Announcement of this action was met with warm approval among librarians, and some publishers complied with the agreement immediately. Lists received from Julius Springer in September, however, showed average reductions of only 9 per cent and even some increases. Protests were at once made to Springer, to the Börsenverein, to the Notgemeinschaft der Deutschen Wissenschaft, and to others. Springer's defense was that his periodicals were not inflated, and, consequently, the Münster agreement did not apply. The matter was called to the attention of the German Imperial Minister of the Interior, who, apparently realizing that the circulation of German publications might be severely restricted because of the impasse which had developed, issued a statement directing authors and publishers to comply with the Münster agreement and if possible to extend it. ${ }^{15}$

Probably as a result of complaints from

14 Brown, Charles H. "Bringing the Periodical Situation Up to Date." A.L.A. Bulletin 27:379-80,

September 1933.
15 Brown, Charles H. "Discussion on German Periodicals." Library Journal 58:978, Dec. 1, 1933. 
libraries, the Börsenverein decided to send two representatives to the annual American Library Association conference at Chicago in October 1933. These delegates were Ferdinand Springer, of the Springer firm, and H. Degener, of the Verlag Chemie. As it turned out, the Chicago Conference, presided over by Mr. Brown, was the climax of all that had gone before. Two closed sessions were held, attended by representatives of the American Library Association, Medical Library Association, and the International Federation of Library Associations. The Börsenverein agents first proposed a year's armistice in order to allow time to work out adjustments. Their plan was rejected by the librarians present. After several days further negotiation, chiefly with Mr. Brown and Mrs. Cunningham, Dr. Springer agreed to make average reductions of 30 per cent in the 1934 prices of twenty-six of his most expensive periodicals and to eliminate all Festschriften and Ergänzungsbände. This agreement, applicable not only to American but to foreign libraries, was announced at the second session on October $18 .^{16}$

\section{Action by Frankfurt Conference}

Upon the return home of the German delegates, a conference was called in Frankfurt on November II to consider the discussions and results of the Chicago meeting. The conference accepted the Chicago agreement, asked that all periodicals costing more than forty gold dollars be reduced at least 30 per cent, and went on record against some of the publishing abuses responsible for high prices. That the principal German publisher, Springer, was acting in good faith was shown by a list of his expensive publications, the maximum prices of which were reduced by 34 per cent for 1934,4 per cent

$$
{ }^{16} \text { Ibid., p. } 978-85 \text {. }
$$

more than promised. ${ }^{17}$ The actual prices were even more favorable- 54 per cent below the 1932 figures, or 24 per cent under the average agreed upon in Chicago. ${ }^{18}$

Economies effected by the German publishers, permitting lower prices, were achieved mainly by reduction in bulk. A comparative study of 1932 and 1934 periodicals, made by Janet Doe, revealed that the number of pages had decreased about 4 per cent more than prices and that the actual page cost in 1934 was 7.7 per cent higher than in 1932. The study also brought out that, even after the price reductions, American libraries were paying an average of more than four times as much per page for German journals as for comparable French and English journals. ${ }^{19}$ It had been understood, however, that no decreases in per page costs would be possible without additional subscriptions. $^{20}$

A further difficulty was German abstracting and indexing periodicals which had been excepted from the price reduction agreement. An English report stated, on the basis of a survey, that six out of fifteen were substantially increased in price from 1934 to 1935. No adjustment for this phase of the problem was ever made. ${ }^{21}$

\section{Effect of Depreciated Dollar}

The devaluation of the American dollar early in 1934 created another crisis for libraries. The depreciated dollar was worth only sixty cents in Germany, therefore practically nullifying benefits gained by libraries in the United States from price reductions.

\footnotetext{
${ }^{17}$ Brown, Charles H. "Supplementary Notes on German Periodicals." Hibrary fournal 59:62-63, Jan. ${ }^{15}$ is ${ }^{1934.4 .}$

18 A.L.A. Bulletin 28:595, September 1934 . September 1035 .

eptember 1935. 30 Brown, Charles H. "Library Budgets and the Cost of Periodicals." A.L.A. Bulletin 28:594-95, September ${ }_{21}^{1934}$ B

21 Bonser, Wilfrid. "The Cost of German Medical 2:155, April 1935.
} 
English libraries were hit in the same way. German publishers were, of course, not responsible for this condition, but it was clear that further concessions would have to be obtained to prevent widespread cancellations of subscriptions. At this point direct action was decided upon by Chairman Brown of the A.L.A. subcommittee. On his own initiative and chiefly at his own expense, he went to Berlin and in May and June I935 discussed with German publishers and government officials the predicament in which American libraries were placed. Some relief was promised, and shortly after Mr. Brown's return, an official message was received from the German government assuring a reduction of 25 per cent in the export prices of German books and periodicals for libraries, effective Aug. I, 1935. (Because of technicalities, the promised reduction actually went into effect on September 9.) This action was probably taken for two principal reasons: Germany's need for foreign exchange and a desire for wide dis- tribution of German publications. ${ }^{22}$

The work of his committee thus largely completed, Mr. Brown submitted a final report at the end of 1935, reviewing the history of the case and acknowledging the aid received by his group from librarians and library associations of many countries. ${ }^{23}$ There is no question that the international cooperation of librarians and scientists was an important factor in bringing the problem to a satisfactory conclusion. On the other hand, without such a leader as $\mathrm{Mr}$. Brown, a constructive solution might have been much longer delayed. As a tribute to him the M.L.A. Committee on the Cost of Current Medical Periodicals stated, "His energy, diplomacy, and tact in dealing with the situation awakened the keenest admiration in all those who have worked with him." ${ }^{24}$ These qualities undoubtedly contributed greatly to the successful outcome.

\footnotetext{
2 Brown, Charles H. "German Periodicals-Further Addenda." Library Journal 60:752-53, Oct. 1, 1935. ${ }^{23}$ "German Periodicals." A.L.A. Bulletin 29:854, 880, December 1935 .

24 Medical Library Association Bulletin $22: 109$, November 1933.
} 